\title{
А.Ю. Демонова ${ }^{1}$, Н.А. Харитонова ${ }^{2}$, А.В. Корзун ${ }^{3}$, А.И. Сардоров ${ }^{4}$, Г.А. Челноков ${ }^{5}$ \\ ХИМИЧЕСКИЙ СОСТАВ АЗОТНЫХ ТЕРМАЛЬНЫХ ВОД БАЛЬНЕОКЛИМАТИЧЕСКОГО КУРОРТА ХОДЖА-ОБИ-ГАРМ (ТАДЖИКИСТАН)
}

\begin{abstract}
Приведены новые данные по макро- и микрокомпонентному составу слабоминерализованных азотных термальных вод месторождения Ходжа-Оби-Гарм (Таджикистан). Установлено, что эти воды содержат повышенное содержание: F, Si, Li, Al, Rb, Sr, Cs. Детальная характеристика геологических и гидрогеологических условий месторождения, а также термодинамические расчеты позволили выявить источники этих элементов. Проведено сравнение с термальными водами других регионов и приведены новые данные о содержании в изучаемых водах редкоземельных элементов и иттрия.

Ключевые слова: азотные термальные воды, гидрогеологические условия, микрокомпоненты, РЗЭ и иттрий, Таджикистан.

The paper presents new data on contents of major and micro components from low TDS nitrogen thermal water located within Khoja-Obi-Garm spa (Tajikistan). It was found that these thermal groundwaters contain high contents of the following components: $\mathrm{F}, \mathrm{Si}, \mathrm{Li}, \mathrm{Al}, \mathrm{Rb}$, $\mathrm{Sr}$, Cs. Detailed study of the geological and hydrogeological settings of the spa together with thermodynamic simulations allows us reveal sources of chemical elements into these waters. It was carried out the comparison of thermal groundwater from Khoja-Obi-Garm spa with the thermal waters of other regions of Eurasia, also new data on the rare earth elements and yttrium (REY) concentrations in studied thermal water are presented.
\end{abstract}

Key words: Alkaline low TDS springs, hydrogeological setting, thermal spa, microcomponents. REYs, Tadjikistan.

Введение. На территории Таджикистана расположен уникальный курорт Ходжа-Оби-Гарм, основной лечебный компонент которого - низкоминерализованные азотные термы. По многим бальнеологическим показателям (температура, радиоактивность, содержание кремнекислоты) эти термы не имеют аналогов в мире. Наиболее активные работы по исследованию геологии, гидрогеологии и гидрогеохимии вод курорта Ходжа-ОбиГарм выполнены в середине прошлого столетия [Барабанов, Дислер, 1968], с тех пор комплексное изучение этих термальных вод не проводилось.

Азотные слабоминерализованные щелочные термальные воды представляют собой крупную группу минеральных вод, обладающих рядом характерных признаков и свойств: высокая температура (до $100{ }^{\circ} \mathrm{C}$ и более); в их газовом составе преобладает $\mathrm{N}_{2}$; минерализация воды различна, но, как правило, низкая (менее 1 г/л). Химический состав изменяется от $\mathrm{HCO}_{3}-\mathrm{Na}$ и $\mathrm{SO}_{4}-\mathrm{Na}$ до $\mathrm{Cl}-\mathrm{Na}$. Еще одна особенность азотных термальных вод наличие в их составе значительных концентраций кремнекислоты, фтора, вольфрама, молибдена, германия и др. [Барабанов, Дислер, 1968; Басков, Суриков, 1989; Замана, 2000; Плюснин и др., 2008; Helvachi, 2004; Bragin et al., 2016].

В статье рассмотрены новые данные о химическом составе термальных вод месторождения Ходжа-Оби-Гарм, с основным акцентом на содержание в них микрокомпонентов, а также редкоземельных элементов и иттрия (REY). Проведенные комплексные исследования геологических, гидрогеологических и гидрогеохимических особенностей месторождения позволили выявить источники поступления и формы водной миграции исследуемых макро- и микрокомпонентов.

Объект исследований. В 48 кM К северу от Душанбе расположен уникальный бальнеоклиматический курорт Ходжа-Оби-Гарм (рис. 1). Курорт локализован в центральной части южного склона Гиссарского хребта, в ущелье р. Ходжа-Оби-Гарм, на высоте 1740-1960 м. В административном отношении описываемый район относится к Варзобскому району.

\footnotetext{
${ }^{1}$ Московский государственный университет имени М.В. Ломоносова, геологический факультет, кафедра гидрогеологии, вед. инженер; e-mail: danna1985@yandex.ru

${ }^{2}$ Московский государственный университет имени М.В. Ломоносова, геологический факультет, кафедра гидрогеологии, профессор, докт. геол.-минерал. н.; гл. науч. c.; e-mail: tchenat@mail.ru

${ }^{3}$ Московский государственный университет имени М.В. Ломоносова, геологический факультет, кафедра гидрогеологии, доцент, канд. геол.-минерал. н.; e-mail: a_korzun@mail.ru

4 Московский государственный университет имени М.В. Ломоносова, геологический факультет, кафедра гидрогеологии, магистр; e-mail: sardorov@mail.ru

5 ДВГИ ДВО РАН, руководитель лаборатории, гл. науч. c.; e-mail: geowater@mail.ru
} 


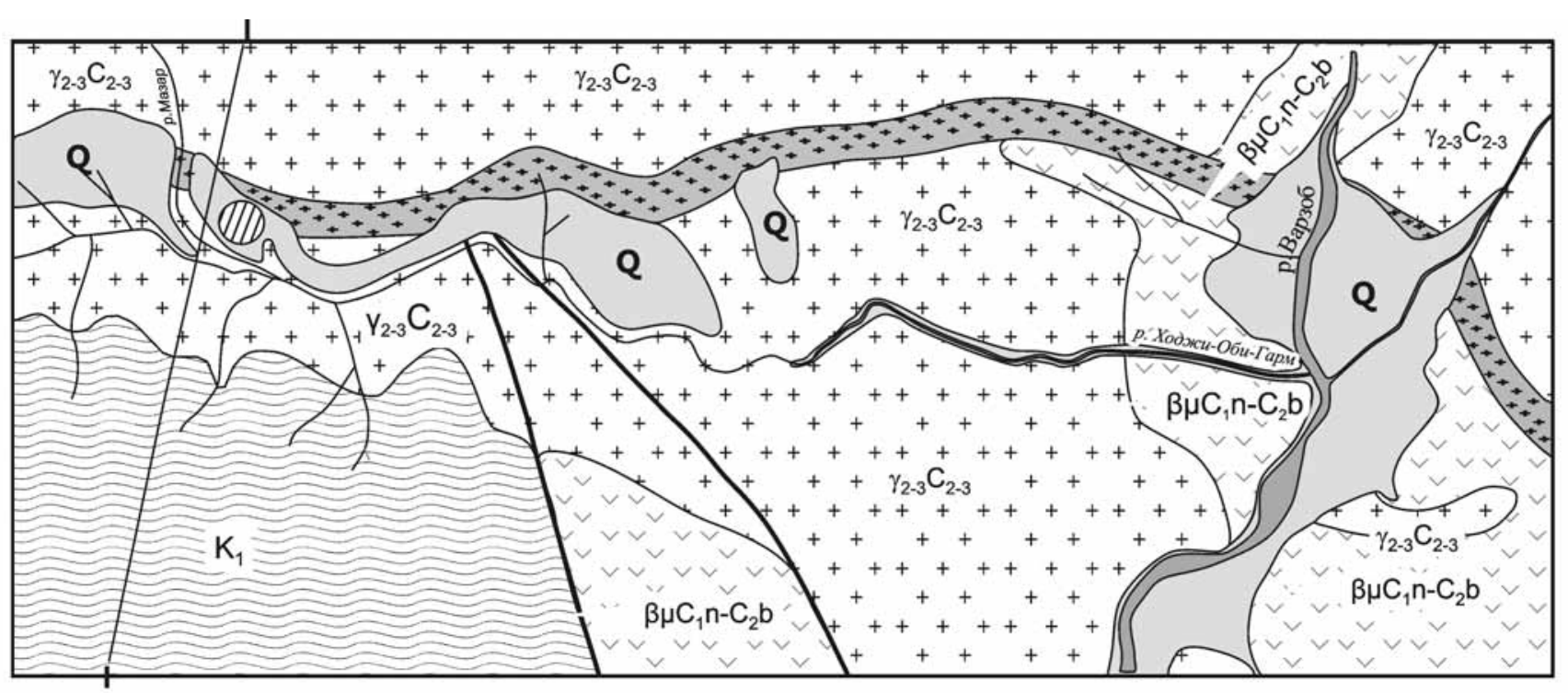

Масштаб 1:5000

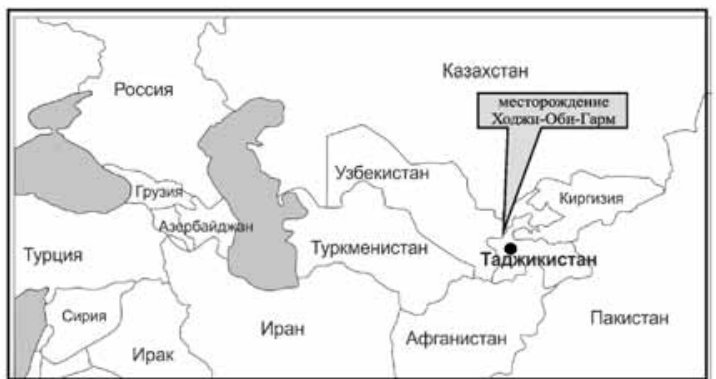

І. Гидрогеологические подразделения $\mathbf{Q} \quad \begin{aligned} & \text { поровые воды в аллювиальных и пролювиальных } \\ & \text { четвертичных отложениях }\end{aligned}$

K водоносный комплекс нижнемеловых отложений. Песчаники, прослои мергеля, известняков

$\beta \mu C_{1} n-C_{2} b$

водоносный комплекс в эффузивной толще верхнего и среднего отделов каменноугольной системы (намюрский, башкирский ярусы). Базальты

$\mathrm{V}_{2,3} \mathrm{C}_{2,3}+$

водоносный комплекс в интрузивных порода средневерхнекаменноутольного возраста. Граниты, гранодиориты, диориты

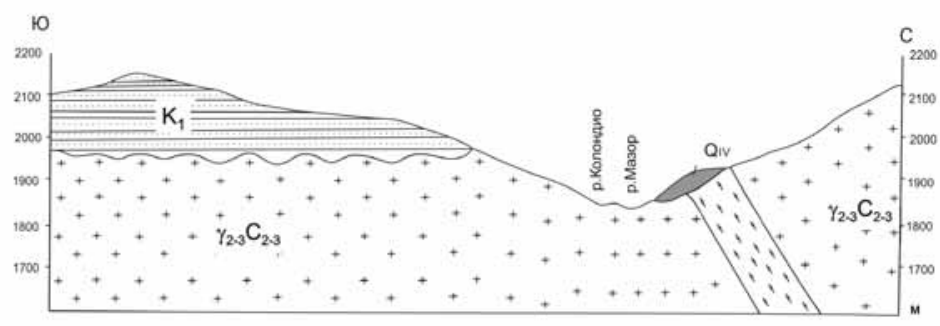

II. Прочие обозначения

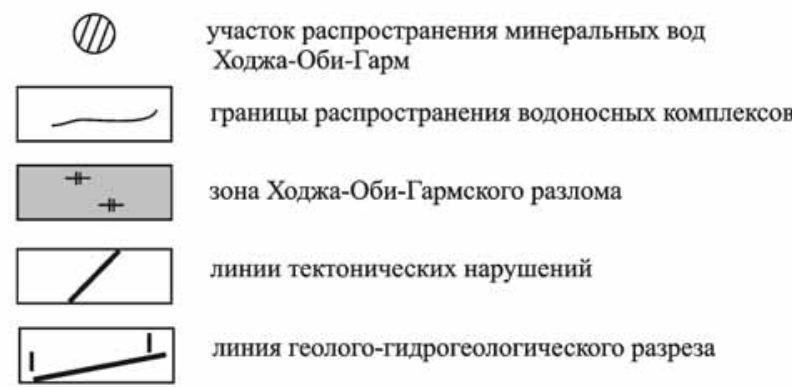

Рис. 1. Местоположение, геолого-гидрогеологическая карта и гидрогеологический разрез-схема месторождения Ходжа-Оби-Гарм. Карта и разрез построены по материалам производственных отчетов [Воронкова, 1957; Шапар, Туев, 1967] с дополнениями и исправлениями авторов

В орографическом отношении изученный район представляет собой высокогорную, сильно расчлененную область, характеризующуюся резким колебанием высотных отметок. Максимальные абсолютные отметки (до 4076 м) отвечают северо-западной части района, а минимальные $(1390-1400$ м) - долине р. Варзоб в восточной части района. Относительные превышения водоразделов над долинами рек весьма значительны и достигают 500-1500 м.

Рельеф описываемой площади находится в строгой зависимости от литологического состава пород. Крупнозернистые граниты и сланцы, легко подающиеся процессам денудации, образуют пологие склоны и водоразделы, покрытые в большинстве случаев дресвой и нередко задернованные.
В областях развития эффузивов, мелкозернистых гранитов, гипабиссальных пород, среднезернистых роговообманково-биотитовых гранитов рельеф скалистый, труднодоступный, местами непроходимый. В местах развития осадочных пород мезозойского возраста развиты пологие формы рельефа.

Месторождение минеральных вод Ходжа-ОбиГарм расположено в верховьях р. Ходжа-Оби-Гарм, левого притока р. Варзоб, и приурочено к тектонической зоне, по которой происходит восходящее движение термальных вод. В геолого-структурном отношении месторождение расположено на северном крыле Ходжа-Оби-Гармской грабенсинклинали. В геологическом строении района в основном принимают участие интрузивные поро- 
Рис. 2. Пайпер-диаграмма, иллюстрирующая химический состав азотных термальных вод некоторых месторождений Евразии. Диаграмма построена по ретроспективным данным химического анализа термальных вод, опубликованным в работах [Иванов, Невраев, 1964; Барабанов, Дислер, 1968; Брагин, 2015; Bragin et al., 2016], а также по результатам химического анализа проб, отобранных авторами на месторождении Ходжа-Оби-Гарм в 2014-2015 гг.

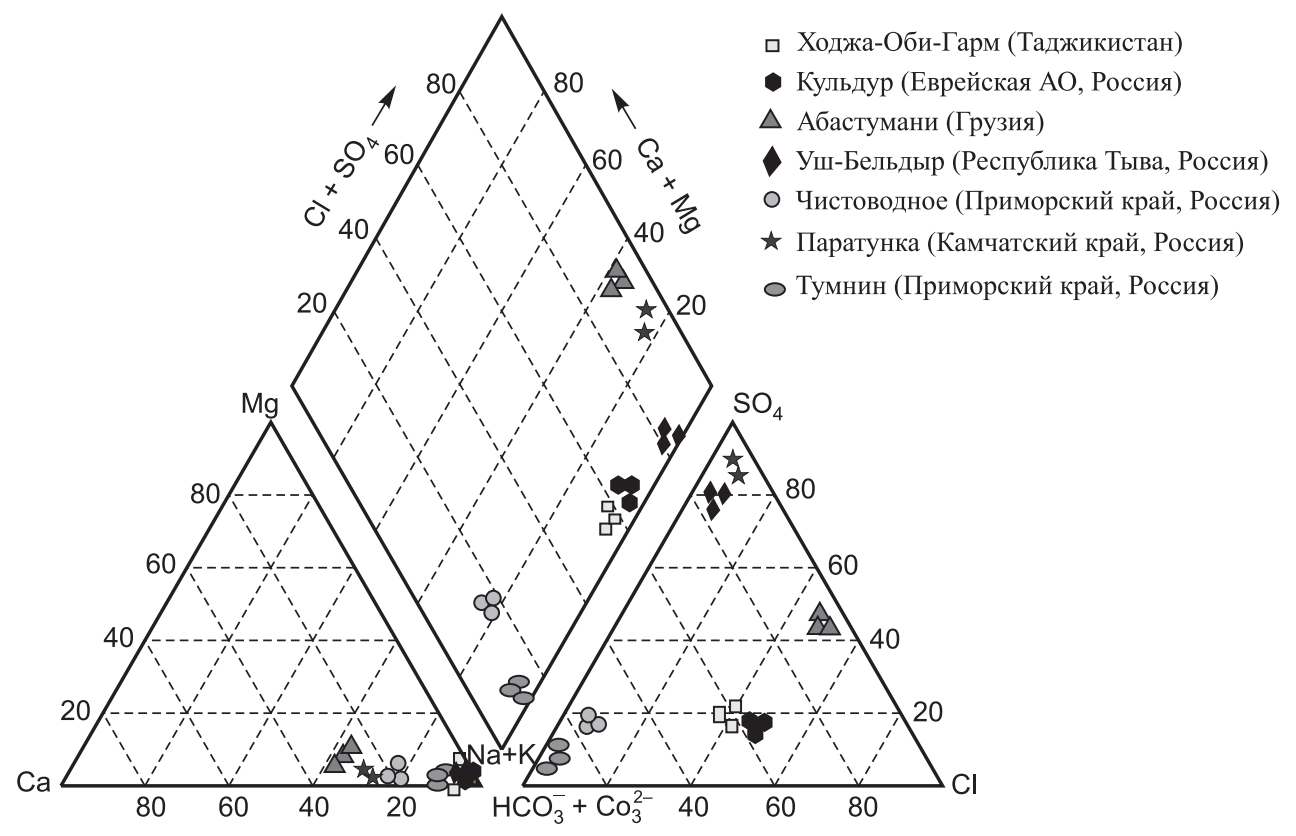

ды южной части Северо-Варзобского интрузивного массива, представленные гранитами, гранодиоритами, гранит-порфирами средне- и раннекаменоугольного возраста. Интрузии перекрыты чехлом четвертичных отложений (рис. 1). В юго-западной части района палеозойские образования перекрыты нижнемеловыми осадками, песчаниками и глинами [Гидрогеология СССР, 1972; Барабанов, Дислер, 1968].

Аллювиально-пролювиальные образования занимают большую часть площади месторождения и представлены отдельными полосами аллювия с перекрывающими их пролювиальными осадками мощностью 10-20 м в центральной и до 40 м в западной части. Обломочный материал представлен валунами, галечниками и гравием гранитоидного состава с супесчаным и песчаным заполнителем.

Пролювиально-делювиальные осадки мощностью от 34 м (скважина № 7) до 54 м (скважина № 4) слагают северную и северо-западную части участка и представлены грубообломочным материалом и более рыхлыми образованиями (дресва кислых пород).

Гидрогеологические условия месторождения сложные и определяются геолого-структурными особенностями участка. По условиям залегания и циркуляции - это трещинно-жильные термальные воды, которые приурочены к мощной зоне дробления гранитов, связанной с Ходжа-Оби-Гармским разломом в месте сочленения его с оперяющим нарушением север-северо-западного простирания [Гидрогеология СССР, 1972; Барабанов, Дислер, 1968].

Распространение трещинно-жильных вод в пределах месторождения весьма ограниченное, водообильность неравномерная. Максимальный расход получен скважинами, вскрывшими основной очаг разгрузки $(50 \times 100$ м $)$ в центральной части участка. Остальными скважинами вскрыто лишь незначительное количество термальных вод, не имеющих практического значения. Расход источников колеблется от 0,01 до 5,00 л/с, источники с максимальным дебитом приурочены к зоне разлома [Гидрогеология СССР, 1972; Барабанов, Дислер, 1968].

Материалы и методы исследований. На первом этапе исследования был проведен сбор, анализ и обработка фактического материала, а также проанализированы фондовые материалы. Непосредственно авторами выполнен отбор проб из источников в полевой период в 2014-2015 гг. Полевое исследование выходов углекислых минеральных вод включало в себя описание источника, отбор проб воды и спонтанного газа на различные виды анализа, а при наличии вторичных отложений - отбор образцов осадка.

Пробы для анализа катионов и сульфатов отфильтровывали через целлюлозный фильтр $(0,45 \mu \mathrm{m})$, на месте отбора для удаления взвеси подкисляли азотной кислотой. Пробы для анализа анионов также фильтровали и собирали в полиэтиленовые пузырьки (без подкисления).

Химические анализы отобранных проб были выполнены в аналитических подразделениях Дальневосточного геологического института ДВО РАН. Был произведен полный химический анализ всех проб воды на 52 элемента на новейшем аналитическом оборудовании. Основные катионы и анионы определялись методом жидкостной ионной хроматографии (HPLC-10 AVp, SHIMADZU). Концентрацию микрокомпонентов и рассеянных элементов измеряли с использованием плазменнооптической эмиссионной спектрометрии (ICPAES, Plasmaquant-110) и индуктивной плазменной масс-спектроскопии (ICP-MS, Agilent 7500c). Точность определения всех компонентов была лучше чем 5\% RSD. 
Расчет индексов насыщения минералов и форм миграции макро- и микрокомпонентов, а также РЗЭ проведен с использованием программных комплексов AQUACHEM 5.1, WATERQ4F, PHREEQC.

Результаты исследований и их обсуждение. Химический состав вод. Термальные источники Ходжа-Оби-Гарм расположены на левом склоне рек Оби-Мазор и Ходжа-Оби-Гарм, их выходы протягиваются вдоль русел этих рек на протяжении 400 м по зоне главного надвига. По гипсометрическому положению источники делятся на две большие группы - верхнюю и нижнюю: а) источники верхней группы расположены на уровне 2-й и 3-й террас на более или менее ровной поверхности; в) источники нижней группы локализованы около дороги, проходящей по надпойменной трассе реки.

Данные многолетних наблюдений (табл. 1) показывают, что химический состав вод стабилен в течение всего периода наблюдений. Характерная черта источников - их высокая температура $\left(63,5-93{ }^{\circ} \mathrm{C}\right)$ и высокая щелочность $(\mathrm{pH} 8,98 \div 9,18)$. Кроме того, обращает на себя внимание исключительно низкая общая минерализация термальных вод месторождения, которая составляет 300-400 мг/л.

По химическому составу термальные воды изучаемого месторождения относятся к хлоридно-сульфатно-гидрокарбонатным натриевокремнистым водам (рис. 2). Практически во всех скважинах среди анионов превалирует ион $\mathrm{HCO}_{3}{ }^{-}\left(\mathrm{CO}_{3}{ }^{2-}\right)$, а основной катион $-\mathrm{Na}^{+}$, содержание которого доходит до 100 мг/л, в то время как содержания $\mathrm{Ca}^{2+}, \mathrm{Mg}^{2+}$ и $\mathrm{K}^{+}$, как правило, низ- ки. Содержание $\mathrm{Ca}^{2+}$ колеблется от 6 до 15 мг/л, $\mathrm{K}^{+}$не более 9 мг/л и $\mathrm{Mg}^{2+}$ - до 1 мг/л. Это типичные содовые воды с резким преобладанием гидрокарбонат-иона и натрия.

Помимо карбонатных ионов $\left(\mathrm{HCO}_{3}{ }^{-}\right.$и $\left.\mathrm{CO}_{3}{ }^{2-}\right)$ в достаточно высоких количествах присутствуют хлор (до 55 мг/л) и сульфат-ион (до 40 мг/л). Концентрация борной кислоты $\left(\mathrm{H}_{3} \mathrm{BO}_{3}\right)$ составляет 6 мг/л. Исследуемые термы богаты фтором, концентрация которого достигает 18 мг/л. Сравнение с азотными термальными водами бывшего СССР показало, что столь высокое содержание фтора также характерно для вод месторождения Кульдур (Еврейская АО) и Уш-Бельдыр (Республика Тыва). Отношение $\mathrm{Cl} / \mathrm{F}$ составляет 3,18. Содержание $\mathrm{CO}_{2 \text { раств }}$ колеблется в диапазоне 2-6 мг/л, а $\mathrm{H}_{2} \mathrm{~S}_{\text {раств }}-3,54$ мг/л.

Сопоставление данных по химическому составу азотных термальных вод месторождения ХоджаОби-Гарм с подобными водами других известных месторождений Евразии приведено на рис. 2.

Термальные воды источников характеризуются большим содержанием кремнекислоты, количество которой в источниках варьирует (от 85,6 до 147 мг/л) и в среднем составляет около 140 мг/л (табл. 1). Установлена практически прямая зависимость между содержанием в растворе натрия и метакремниевой кислоты, что свидетельствует об одном минеральном источнике для этих компонентов, вероятнее всего это натриевый полевой шпат (альбит), один из основных породообразующих минералов водовмещающих пород месторождения.

При оценке вклада основных ионов в минерализацию очевидно, что к основным компонентам,

Репрезентативный химический состав термальных вод месторождения Ходжа-Оби-Гарм, мг/л

Таблица 1

\begin{tabular}{|c|c|c|c|c|c|c|c|c|c|c|c|c|c|c|c|}
\hline 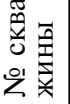 & M & $\mathrm{pH}$ & $T,{ }^{\circ} \mathrm{C}$ & $\mathrm{K}^{+}$ & $\mathrm{Na}^{+}$ & $\mathrm{Mg}^{2+}$ & $\mathrm{Ca}^{2+}$ & $\mathrm{Cl}^{-}$ & $\mathrm{Br}^{-}$ & $\mathrm{SO}_{4}^{2-}$ & $\mathrm{HCO}_{3}^{-}$ & $\mathrm{CO}_{3}^{-}$ & $\mathrm{F}^{-}$ & $\mathrm{H}_{2} \mathrm{SiO}_{3}$ & $\mathrm{HBO}_{2}$ \\
\hline 6 & 0,40 & 7,1 & 65,5 & 4,4 & 61,5 & 2,0 & 20,8 & 35,5 & 0,1 & 49,5 & 93,3 & 6,0 & 17,0 & 103,5 & 1,0 \\
\hline 7 & 0,41 & 7,6 & 61,9 & 7,4 & 93,7 & 1,5 & 11,3 & 44,2 & 0,2 & 89,3 & 74,5 & 15,0 & 16,9 & 113,0 & 1,0 \\
\hline 9 & 0,40 & 7,7 & 69,9 & 8,0 & 84,0 & - & 9,0 & 43,0 & - & 71,0 & 61,0 & 18,0 & 15,4 & 78,0 & - \\
\hline 12 & 0,40 & 7,3 & 57,6 & 6,9 & 79,2 & 1,1 & 14,2 & 43,6 & 0,1 & 67,6 & 106,2 & 12.0 & - & 104,8 & 1,3 \\
\hline 14 & 0,44 & 8,0 & 65,0 & 10,0 & 96,0 & - & 4,0 & 53,0 & - & 54,0 & 49,0 & 36,0 & - & 139,0 & - \\
\hline 15 & 0,40 & 7,6 & 83,7 & 8,0 & 82,0 & 1,1 & 9,0 & 39,3 & 0,1 & 84,3 & 63,0 & 14,0 & - & 93,0 & 1,0 \\
\hline 16 & 0,36 & 7,6 & 78,3 & 7,5 & 84,0 & 0,7 & 10,5 & 42,9 & 0,3 & 59,4 & 102,7 & 30,0 & - & 103,3 & - \\
\hline 1 & 0,38 & 7,3 & 93,0 & 11,2 & 75,3 & - & 16,3 & 43,7 & 0,1 & 71,0 & 73,3 & - & - & 90,7 & 1,0 \\
\hline 3 & 0,42 & 7,1 & 93,0 & 9,0 & 82,2 & 1,2 & 16,0 & 41,2 & 0,3 & 39,6 & 105,0 & - & - & 80,6 & 1,0 \\
\hline $4-\Gamma$ & 0,30 & 7,5 & 93,0 & 6,0 & 85,0 & 1,0 & 4,0 & 50,0 & - & 46,0 & 68,0 & - & 17,1 & 104,0 & - \\
\hline $2-\Gamma$ & 0,37 & 7,5 & 93,0 & 6,0 & 85,0 & 1,3 & 4,0 & 50,0 & 0,1 & 47,6 & 54,0 & - & - & 123,7 & - \\
\hline $6-\Gamma$ & 0,35 & 7,4 & 93,0 & 6,0 & 86,5 & 2,0 & 4,5 & 48,5 & 0,2 & 51,0 & 77,5 & - & - & 117,0 & 1,0 \\
\hline $7-\Gamma$ & 0,40 & 7,4 & 93,0 & 5,5 & 83,5 & 2,5 & 6,5 & 50,0 & 0,1 & 58,5 & 73,0 & - & - & 117,0 & 1,0 \\
\hline
\end{tabular}

Примечание: М - минерализация, прочерк - нет данных. 
обеспечивающим минерализацию вод, относятся натрий, калий, кремний, хлор и фтор, сульфат-ион и карбонаты.

Термодинамические расчеты показали, что термальные воды Ходжа-Оби-Гарм недосышены по отношению ко всем основным аллюмосиликатам: по альбиту (индекс насыщения (ИН) варьирует от $-0,16$ до $-0,32)$, по анортиту (ИН лежит в диапазоне значений $-5,96 \div-6,28)$ и слюдам, а также по всем карбонатным минералам и пересыщены по отношению к кварцу и его модификациям, калиевому полевому шпату и глинистым минералам (смектиту, иллиту, каолиниту), а также по группе низкотемпературных цеолитов (гейландиту, клиноптилолиту, мордениту). Ионная сила раствора составляет 0,0055 .

Можно предположить, что дождевая вода состава $\mathrm{Na}-\mathrm{HCO}_{3}-\mathrm{Cl}$, просачиваясь в зону формирования грунтовых вод, накапливает преимущественно кальций и гидрокарбонат-ион за счет разложения почвенной органики, что приводит к образованию $\mathrm{Ca}-\mathrm{Na}-\mathrm{Mg}-\mathrm{HCO}_{3}$ грунтовых вод. При дальнейшем погружении и нагревании вод происходит преимущественное накопление натрия за счет разложения в первую очередь плагиоклазов. В результате образуются воды состава $\mathrm{Na}-\mathrm{HCO}_{3}$. Данные С.Р. Крайнова и Б.Н. Рыженко [Krainov, Ryzhenko, 1996] о моделировании в системе гранит-вода показывают, что на начальном этапе взаимодействия при отношении вода:порода $>>1$ происходит формирование слабоминерализованных $\mathrm{HCO}_{3}-\mathrm{Na}$ вод. Следует отметить, что в системе вода-гранит жидкая фаза при температуре $>25{ }^{\circ} \mathrm{C}$ и давлении до 5 кбар имеет щелочную реакцию.

Несмотря на многолетние исследования, вопрос об источниках фтора в термальных водах до сих пор остается спорным, правда, подавляющее большинство исследователей склоняются к мнению, что фтор поступает из вмещающих пород, тем не менее механизм его мобилизации из горных пород трактуется неоднозначно [Плюснин и др., 2008]. Полученные нами данные показывают, что содержание F в исследованных термах достаточно хорошо коррелирует с концентрацией карбонатных ионов, но плохо - с сульфатами. Кроме того, наблюдается положительная корреляция содержания фтора с содержанием $\mathrm{SiO}_{2}$ и температурой. Это, возможно, свидетельствует о идентичности источников фтора, кремния и натрия. Наиболее вероятно, что поступление всех этих компонентов в воды вызвано растворением алюмосиликатов, т.е. F поступает в водный раствор в результате их гидролиза, при этом чем длительнее растворение материнского минерала, тем больше фтора поступает в водный раствор.

Расчет форм нахождения основных ионов в растворе показал, что до 99\% катионов находится в ионной форме.
Микрокомпонентный состав вод. В 20142015 гг. получены новые данные о микрокомпонентном составе термальных вод месторождения (табл. 2). Анализ результатов показывает, что среди сидерофильной группы элементов значимую концентрацию в водах имеют только железо, марганец, молибден, кобальт, никель. Содержание $\mathrm{Fe}_{\text {общ }}$ в термальных водах месторождения ХоджаОби-Гарм низкое и составляет 60-140 мкг/л. Содержание кобальта невысокое и находится в диапазоне 0,013-0,039 мкг/л. Концентрация никеля в источниках варьирует и может отличаться в разных скважинах почти на порядок, что вызвано, вероятно, неравномерным концентрированием элемента в водовмещающих породах.

Таблица 2

Средние содержания микроэлементов в термальных водах месторождения Ходжа-Оби-Гарм, мкг/л

\begin{tabular}{|c|c|c|c|c|c|}
\hline 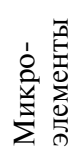 & 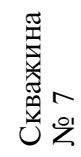 & 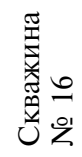 & 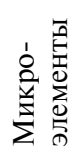 & 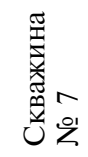 & 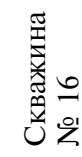 \\
\hline $\mathrm{Li}$ & 991 & 953 & $\mathrm{Zn}$ & 1,8 & 1,6 \\
\hline $\mathrm{Be}$ & 0,48 & 0,58 & $\mathrm{Ga}$ & 6,19 & 5,02 \\
\hline $\mathrm{Al}$ & 122 & 77 & As & 5,31 & 4,96 \\
\hline $\mathrm{Sc}$ & 0,09 & 0,06 & $\mathrm{Se}$ & 0,12 & 0,11 \\
\hline V & 0,17 & 0,08 & $\mathrm{Rb}$ & 116 & 111 \\
\hline $\mathrm{Cr}$ & 0,11 & 0,07 & $\mathrm{Sr}$ & 168 & 160 \\
\hline $\mathrm{Mn}$ & 2,53 & 4,11 & $\mathrm{Ag}$ & 0,035 & 0,003 \\
\hline $\mathrm{Fe}$ & 104 & 79 & $\mathrm{Cd}$ & 0,04 & 0,03 \\
\hline $\mathrm{Co}$ & 0,04 & 0,01 & Cs & 219 & 211 \\
\hline $\mathrm{Ni}$ & 0,42 & 0,07 & $\mathrm{Ba}$ & 1,6 & 1,3 \\
\hline $\mathrm{Cu}$ & 1,45 & 0,85 & $\mathrm{~Pb}$ & 3,34 & 0,28 \\
\hline
\end{tabular}

Среди халькофильных элементов особого внимания заслуживают такие элементы, как медь, цинк, галлий, мышьяк, селен, серебро, кадмий и свинец. Содержание меди в изученных термальных водах достаточно низкое, не превышает 2,2 мкг/л (табл. 2). Концентрация цинка также невысока и находится в диапазоне 0,8-2,0 мкг/л. Обнаружена довольно высокая концентрация галлия, мышьяка и свинца (мкг/л): $3,85-7,21 ; 4,58-5,69$ и 0,44-5,49 соответственно. Содержание серебра и кадмия очень низкое и не превышают $0,0 n$ мкг/л (табл. 2).

Среди литофильных элементов очень высокая концентрация (мкг/л) выявлена для лития $(0,9-1,03)$, рубидия $(107,3-122,6)$, стронция $(151,7-169,2)$, цезия (204-231) и алюминия $(0,48-126,5)$. Концентрация марганца невысока $(1,18-7,04$ мкг/л), а ванадия, хрома и бария очень низкая и не превышает несколько мкг/л. Содержание бора невелико и составляет всего 0,31-0,34 мг/л. Отношение B:Cl равно 0,006, что 
практически в 4 раза меньше, чем в морской воде, и почти совпадает с этим показателем $(0,04-0,007)$ в термальных источниках областей активного вулканизма. Соотношение $\mathrm{Cl}: \mathrm{Br}=257$ и очень близко к таковому в морских водах (293).

Соотношение Li:Rb:Сs составляет 100:12:23, это несколько выше, чем соотношение этих элементов в термальных водах Камчатки (Li:Rb:Cs=100:9:10) или в среднем в термальных водах Земли (100:13:14).

Термальные воды месторождения Ходжа-ОбиГарм обогащены радоном - его концентрация составляет 22 нКи/л $(814$ БК/л) - и характеризуются слабой радиоактивностью, что связано с условиями их формирования и циркуляции. Повсеместно в термальных водах, формирующихся в осадочных карбонатных и песчано-глинистых породах, содержание радона обычно колеблется в пределах 1-3 нКи/л (37-111 Бк/л), в то время как термальные источники, локализованные в массивах кристаллических пород, содержат радона до 20 нКи/л (740 Бк/л). Столь высокое содержание Ra обнаружено в водах месторождений Белокуриха, Рахмановское, Копал-Арсан, Ак-Су, Гармчашма, Хахдаре и др.

Установлено, что накопление радона в термальных водах зависит не только от типа водовмещающих пород, но и от эманирующей способности горных пород, размеров трещин и скорости движения подземных вод. При вскрытии скважинами зон и очагов с повышенной концентраций радия на ряде месторождений получены более радиоактивные воды, чем те, которые наблюдались при естественных выходах (Цхалтубо, Белокуриха, Ходжа-Оби-Гарм и др.). Отметим, что радиоактивность вод - один из бальнеоло-

Таблица 3

Концентрация РЗЭ и иттрия в термальных водах месторождения Ходжа-Оби-Гарм и в азотных термах Сихотэ-Алиня (мкг/л)

\begin{tabular}{|c|c|c|c|c|c|c|c|c|}
\hline \multirow{3}{*}{ Элементы } & \multicolumn{4}{|c|}{ Месторождение Ходжа-Оби-Гарм } & \multirow{3}{*}{$\begin{array}{c}\text { Источник } \\
\text { Сайон* }\end{array}$} & \multirow{3}{*}{$\begin{array}{l}\text { Источник } \\
\text { Кхутцин* }\end{array}$} & \multirow{3}{*}{$\begin{array}{c}\text { Источник } \\
\text { Чистоводное* }\end{array}$} & \multirow{3}{*}{$\begin{array}{c}\text { Источник } \\
\text { Феруза (Памир) }\end{array}$} \\
\hline & \multicolumn{2}{|c|}{ скважина № 7} & \multicolumn{2}{|c|}{ скважина № 16} & & & & \\
\hline & минимум & максимум & минимум & максимум & & & & \\
\hline $\mathrm{La}$ & 0,085 & 0,158 & 0,004 & 0,09 & 0,007 & 0,008 & 0,013 & 0,0928 \\
\hline $\mathrm{Ce}$ & 0,138 & 0,292 & 0,011 & 0,156 & 0,016 & 0,009 & 0,016 & 0,014 \\
\hline $\operatorname{Pr}$ & 0,016 & 0,04 & 0,001 & 0,021 & 0,002 & 0,003 & 0,004 & 0,0157 \\
\hline $\mathrm{Nd}$ & 0,063 & 0,168 & 0,004 & 0,079 & 0,007 & 0,011 & 0,016 & 0,0583 \\
\hline $\mathrm{Sm}$ & 0,014 & 0,041 & 0,001 & 0,015 & 0,002 & 0,003 & 0,004 & 0,0103 \\
\hline $\mathrm{Eu}$ & 0,003 & 0,008 & $<\Pi О$ & 0,003 & 0,001 & 0,0005 & 0,0004 & 0,0050 \\
\hline Gd & 0,014 & 0,042 & 0,001 & 0,016 & 0,002 & 0,003 & 0,004 & 0,0131 \\
\hline $\mathrm{Tb}$ & 0,002 & 0,006 & $<\Pi О$ & 0,002 & 0,0003 & 0,0005 & 0,0007 & 0,0020 \\
\hline Dy & 0,009 & 0,03 & $<\Pi О$ & 0,012 & 0,001 & 0,002 & 0,004 & 0,0134 \\
\hline Ho & 0,002 & 0,005 & $<$ ПО & 0,002 & 0,0003 & 0,0005 & 0,001 & 0,0035 \\
\hline $\mathrm{Er}$ & 0,006 & 0,015 & 0,006 & $<\Pi$ & 0,001 & 0,001 & 0,003 & 0,0099 \\
\hline $\mathrm{Tm}$ & 0,001 & 0,002 & 0,001 & $<\Pi$ & 0,0001 & 0,0002 & 0,003 & 0,0015 \\
\hline $\mathrm{Yb}$ & 0,004 & 0,011 & $<\Pi О$ & 0,005 & 0,001 & 0,001 & 0,002 & 0,0083 \\
\hline $\mathrm{Lu}$ & 0,001 & 0,002 & 0,001 & $<\Pi$ & 0,0001 & 0,0001 & 0,0004 & 0,0012 \\
\hline $\mathrm{Y}$ & 0,055 & 0,138 & 0,002 & 0,064 & н.д. & н.д. & н.Д. & 0,201 \\
\hline$\sum_{\text {P3Э }}$ & 0,358 & 0,82 & 0,023 & 0,41 & 0,040 & 0,043 & 0,072 & 0,249 \\
\hline$\sum_{\text {ЛРЗЭ }}$ & 0,319 & 0,707 & 0,021 & 0,365 & 0,035 & 0,035 & 0,053 & 0,196 \\
\hline$\Sigma_{\text {ТР3Э }}$ & 0,039 & 0,113 & 0,002 & 0,045 & 0,006 & 0,008 & 0,018 & 0,053 \\
\hline ЛРЗЭ, \% & 86,2 & 89,1 & 89 & 91,9 & 86,0 & 80,6 & 74,7 & 78,8 \\
\hline $\mathrm{Eu} / \mathrm{Eu}^{*}$ & $-0,003$ & $-0,036$ & 0,001 & 0,089 & $-0,580$ & $-0,778$ & $-1,000$ & 0,283 \\
\hline $\mathrm{Ce} / \mathrm{Ce}^{*}$ & $-0,096$ & $-0,095$ & $-0,103$ & 0,079 & 0,550 & 0,214 & 0,275 & $-1,109$ \\
\hline Dy/Dy* & $-0,117$ & $-0,068$ & $-0,210$ & $-0,089$ & 0,523 & 0,602 & 0,673 & $-0,105$ \\
\hline Ho/Ho* & 0,039 & 0,099 & 0,099 & 0,520 & $-0,523$ & $-0,477$ & $-0,544$ & 0,124 \\
\hline
\end{tabular}

Примечания. <ПО - ниже предела обнаружения прибора; н.д. - нет данных, * - данные из [Bragin et al., 2016]; $\mathrm{Ce} / \mathrm{Ce}^{*}=\log \left(2 \mathrm{Ce}^{*}\right) /\left(\mathrm{La}^{*}+\mathrm{Pr}^{*}\right) ; \mathrm{Eu} / \mathrm{Eu}^{*}=\log \left(2 \mathrm{Eu}^{*}\right) /\left(\mathrm{Sm}^{*}+\mathrm{Gd}^{*}\right) ; \mathrm{Dy} / \mathrm{Dy} *=\log \left(2 \mathrm{Dy}^{*}\right) /\left(\mathrm{Tb}^{*}+\mathrm{Ho}^{*}\right) ; \mathrm{Ho} / \mathrm{Ho}^{*}=\log \left(2 \mathrm{Ho}^{*}\right) /\left(\mathrm{Dy}^{*}+\mathrm{Er}^{*}\right)$; $\mathrm{Ce}^{*}, \mathrm{La}^{*}, \mathrm{Pr}^{*}, \mathrm{Eu}^{*}, \mathrm{Sm}^{*}, \mathrm{Gd}^{*}, \mathrm{Dy} *, \mathrm{~Tb}^{*}, \mathrm{Ho}^{*}, \mathrm{Er}^{*}$ - нормализованное значение элемента по отношению к североамериканскому сланцу. 
Рис. 3. Нормализованные графики распределения РЗЭ азотных термальных вод некоторых месторождений Евразии: 1 - скважина № 7 , месторождение Ходжа-ОбиГарм; 2 - скважина № 16, месторождение Ходжа-ОбиГарм; 3 - углекислые минеральные воды Памира, источник Феруза; 4 - геотермы Камчатки, источник Карымшина [Чудаев и др., 2016]; 5 - геотермы Средней Паратунки, Камчатка [Чудаев и др., 2016]; 6 - азотные термы Сихотэ-Алиня, Приморье [Bragin et al., 2016]; 7 - геотермы Верхней Паратунки, Камчатка [Чудаев и др., 2016]

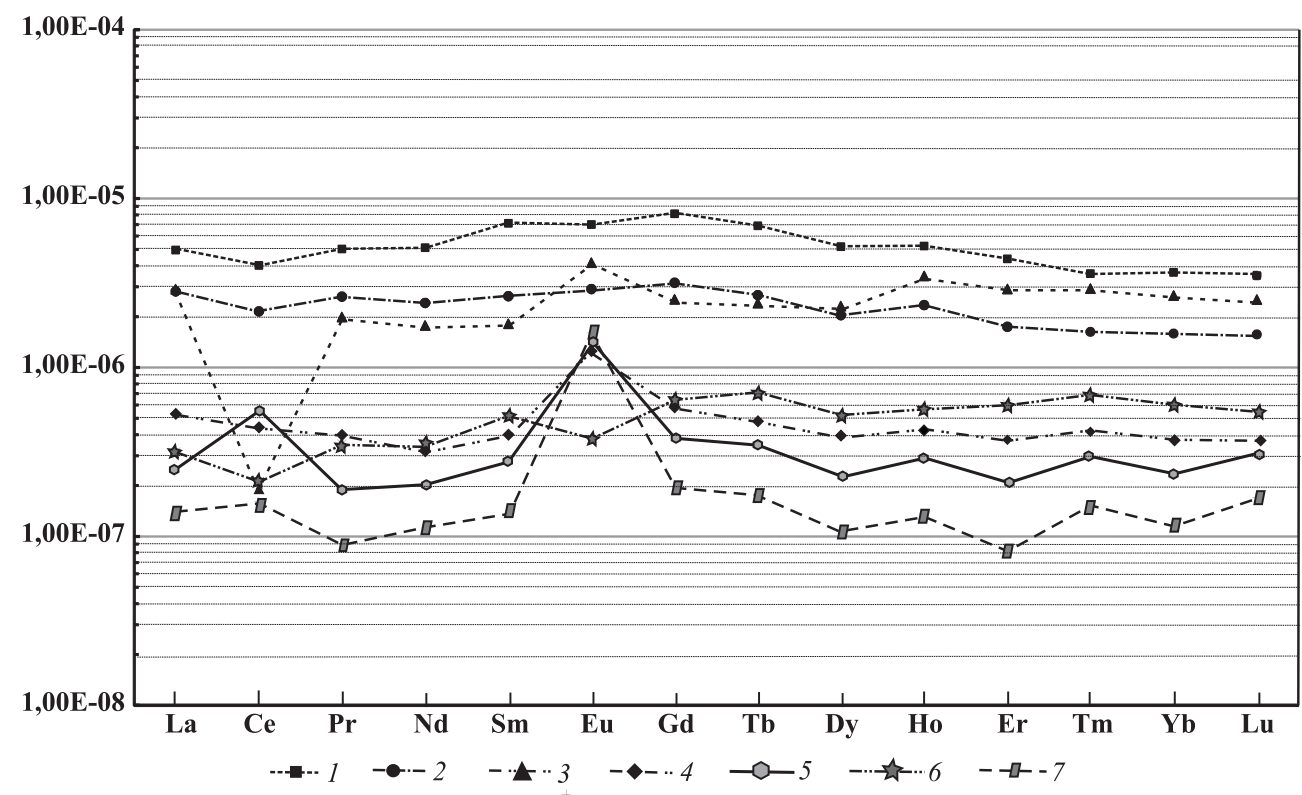

гических компонентов, определяющих лечебное значение азотных слабоминерализованных терм, поэтому при оценке их терапевтического значения необходимо учитывать концентрацию в них радона.

В статье приведены первые данные по содержанию редкоземельных элементов и иттрия в исследуемых термальных водах (табл. 3). Концентрация РЗЭ в рассматриваемых термальных водах в целом низкая и не превышает 1 мкг/л, а основная часть РЗЭ в растворе представлена легкими РЗЭ (более 80\%). Столь небольшая концентрация РЗЭ в водах обусловлена рН термальных вод, который контролирует содержание РЗЭ в воде. Именно щелочные значения рН приводят к уменьшению количества РЗЭ [Sholkovitz, 1995].

Нормализованные спектры распределения РЗЭ, представленные на рис. 3, довольно гладкие, с небольшим подъемом в области средних значений концентрации РЗЭ. Во всех изученных азотных термах присутствует отчетливо выраженная отрицательная цериевая аномалия, значения отношения $\mathrm{Ce} / \mathrm{Ce}$ * варьируют от $-0,1$ до $-0,96$ (табл. 3), что позволяет предположить окисление $\mathrm{Ce}^{3+}$ до $\mathrm{Ce}^{4+}$ в этом типе вод. Се - высокочувствительный компонент к реакции водной среды, его миграция происходит главным образом в виде комплексных соединений, коллоидов и взвесей. Окислительная обстановка подтверждается значениями окислительно-восстановительного потенциала (Eh), варьирующими от +300 до +500 мВ. Видимо, именно изменение валентности Се способствует его преимущественному удалению из воды и соосаждению с коллоидами (или новообразованными минеральными фазами).

Кроме того, в исследованных водах выявлена отрицательная аномалия диспрозия (абсолютные значения варьируют от $-0,07$ до $-0,21)$, а также положительная аномалия гольмия (значения ва- рьируют от 0,09 до 0,52). Природа этих аномалий пока не выяснена и нуждается в дальнейших исследованиях.

В отличие от многих термальных вод, формирующихся в массивах кристаллических пород [Bragin et al., 2016; Чудаев и др., 2016], в водах месторождения Ходжа-Оби-Гарм не обнаружена положительная аномалия европия (рис. 3), хотя основной минерал водовмещающих термальных вод представлен альбитом, и именно с его растворением обычно связывают пик европия в водах. Возможно, отсутствие европиевой аномалии в этих водах определено низкой концентрацией бария в воде.

Заключение. Гидрогеохимические исследования термальных вод месторождения Ходжа-Оби-Гарм показали, что к их характерным особенностям относятся высокая температура $\left(57,6-93{ }^{\circ} \mathrm{C}\right)$ и щелочность (рН 7,1-8). Кроме того, выявлена исключительно низкая общая минерализация термальных вод месторождения (<300-400 мг/л). По химическому составу воды хлоридно-сульфатногидрокарбонатные натриево-кремнистые и содержат повышенную концентрацию F, Si, Li, Al, Rb, Sr, Cs, а также обогащены радоном (до 22 нКи/л). Соотношение $\mathrm{B}: \mathrm{Cl}$ не превышает 0,006 и практически совпадает с таковым в термальных источниках областей активного вулканизма. Корреляционные

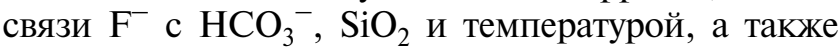
расчет индексов насыщения минералов позволяют предположить один источник для макро- и микрокомпонентов термальных вод, а именно растворение породообразующих аллюмосиликатов. Концентрация РЗЭ в данных термальных водах в целом низкая (<1 мкг/л), причем более $80 \%$ РЗЭ составляют легкие РЗЭ. Для всех вод установлена отчетливая отрицательная цериевая аномалия, которая свидетельствует об окислении церия $\mathrm{Ce}^{+3}$ до церия $\mathrm{Ce}^{+4}$. 


\section{СПИСОК ЛИТЕРАТУРЫ}

Барабанов Л.Н., Дислер В.Н. Азотные термы СССР / Отв. ред. В.В. Иванов. М.: Геоминвод ЦНИИ КиФ, 1968. $120 \mathrm{c}$.

Басков Е.А., Суриков С.Н. Гидротермы Земли. М.: Недра, 1989. 245 с.

Брагин И.В., Челноков Г.А., Чудаев О.В., Харитонова $H . A$. Особенности взаимодействия вода-порода при формировании месторождений термальных вод СихотэАлиня // Материалы Второй Всероссийской конференции с международным участием «Геологическая эволюция взаимодействия воды с горными породами». Владивосток: Дальнаука, 2015. С. 96-99.

Гидрогеология СCCP. T. XLI. Таджикская CCP / Ред. В.С. Самарина. М.: Недра, 1972. С. 472.

Замана Л.В. О происхождении сульфатного состава азотных терм Байкальской рифтовой зоны // Докл. РАН. 2000. T. 327, № 3. С. 361-363.

Иванов В.В., Невраев Г.А. Классификация подземных минеральных вод. М.: Недра, 1964. 167 с.

Плюснин А.М., Чернявский М.К., Посохова В.Ф. Условия формирования гидротерм Баргузинского Прибайкалья по данным микроэлементного и изотопного состава // Геохимия. 2008. № 10. С. 10-63.

Чудаев О.В., Челноков Г.А., Брагин И.В., Харитонова Н.A. и др. Геохимические особенности распределения основных и редкоземельных элементов в Паратунской и Большебанной гидротермальных системах Камчат- ки // Тихоокеанская геология. 2016. Вып. 35, № 6. C. $102-119$.

Bragin I.V., Chelnokov G.A., Chudaev O.V. et al. Geochemistry of thermal waters of continental margin of far east of Russia // Acta Geol. Sinica. 2016. Vol. 90, N 1. P. 276-284.

Chelnokov G., Bragin I., Kharitonova N, Chelnokova $B$. Hydrochemistry of low-temperature thermal water of Primorye region (Russia) and environmental implications // J. Water Res. and Hydraulic Engineering. 2015. Vol. 3. P. 95-98.

Helvachi $C$. Hydrogeochemical and hydrogeological integration of thermal waters in the Emet area (Kutahya,Turkey) // Appl. Geochem. 2004. N 1. P. 105118.

Kharitonova N.A., Vakh E.A., Chelnokov G.A. et al. Ree geochemistry in groundwater of the Sikhote-Alin fold region (Russian Far East) // Russ. J. Pacific Geology. 2016. Vol. 10, N 2. P. 141-154.

Krainov S.R., Ryzhenko B.N. Modeling geochemical processes in a granite-water system with volatile anionforming components in the context of thermal groundwater geochemistry // Geochem. Intern. 1996. Vol. 34, N 3. P. 203-215.

Sholkovitz E.R. The Aquatic chemistry of rare earth elements in rivers and estuaries // Aquatic Geochemistry. 1995. Vol. 1, N 1. P. 1-34. 